\title{
First report of amphizoic amoebae isolated from edible Oyster mushroom- Pleurotus sajor-caju (Singer, 1949)
}

\section{K avyanjali Shukla* and A.K. Sharma}

Protozoology Research Laboratory, Department of Zoology, University of Lucknow, Lucknow- 226007 (U.P.), INDIA *Address: D-1/258, Sector-F, Jankipuram, Lucknow- 226021 (U.P.), INDIA

*Corresponding author. E-mail: shuklakavyanjali@yahoo.com

\begin{abstract}
The present document serves as the first evidence that describes the presence of amphizoic amoebae in cap, stalk and internal tissues such as gills of the edible Oyster mushrooms, Pleurotus sajor-caju, packaged, and sold for public consumption. Samples tested over a 9 month period from different vegetable markets of Lucknow city revealed that out of 180 mushrooms, 176 (97.77\%) yielded amphizoic amoebae, namely, Schizopyrenus, Naegleria, Hartmannella, Acanthamoeba and Vanella sp. Four samples of internal tissues yielded 6 strains of amoebae. A total of $17 \mathrm{Naegleria}$ strains were isolated, out of which 5 were identified as Naegleria fowleri and were tested for their pathogenicity. The strains $2 \mathrm{BNf01}$ and 5BNf04 were mildly pathogenic and strains, 4ANf02, 4ANf03 and 8ANf05, were highly pathogenic. It was also observed that the most frequently observed species of amoebae belonged to the genus Acanthamoeba and a total 103 Acanthamoeba strains recorded.
\end{abstract}

Keywords- Amphizoic amoebae, Oyster mushroom, Pleurotus sajor-caju

\section{INTRODUCTION}

Till date, amoebae have been reported and isolated from a variety of edible biological products of plant origin such as Oak leaf lettuce (Lactuca sativa var. crispa) and Boston lettuce (L. sativa var. capitata) (Napolitano and Eggolt, 2007), vegetables such as turnip (Srivastava et al., 1996), carrot (Sharma et al., 2004), cucumbers, cabbage, lettuce, celery, radishes, tomatoes, cauliflowers and spinach (Rude et al., 1984, Gourabathini, 2008). Several species of amoebae have also been found associated with fresh vegetables. The discovery that amoebae may be isolated from the internal tissues of the cap and stalk, as well as from the surface of the basidiomycete Laccaria trullisata collected at the Hempstead Lake State Park on Long Island, New York (Napolitano and Flanagan, 1980) has raised new questions about the occurrence of amoebae in and on other kinds of mushrooms. This is the first report describing the presence of amphizoic amoebae in Oyster mushroom, Pleurotus sajor-caju packaged, and sold for public consumption.

\section{MATERIALS AND METHODS}

All mushrooms (Pleurotus sajor-caju) were purchased either loose or previously packaged from local stores. Moreover, care was taken to use a variety of suppliers representing different localities in Lucknow city. All mushrooms were purchased, tested and used directly. A total of 180 samples were tested over a period of 9 months ie; from January 2010 to September 2010. Sampling was done twice a month. Methods for aseptic removal of internal tissues from the cap and stalk utilized in the present study was done following methods of other workers such as (Napolitano and Flanagan, 1980). Isolation of amoebae was performed by following the standard methods of Singh and Hanumaiah (1979). For clonal monobacterial culture of amoebae, the cyst from positive culture plates were taken and put in sterile distilled water in glass cavity slides. When cysts sett̂les down on glass surface and were well separated from each other, a single cyst was picked up with a fine sterile micropipette, made of soft glass, under low power of microscope and transferred to non-nutrient agar plates seeded with Escherichia coli. Plates were incubated at $37^{\circ} \mathrm{C}$. Well grown amoebae were studied and identified on the morphological basis of trophozoites, cysts and flagellates following Singh (1981) and the latest classification of protozoa (Levine et al., 1980).

The pathogenicity test of amphizoic amoebae was performed on laboratoryalbinomice weighing up to 12 to 15 gms choosing the strains of Naegleria fowleri which is regarded the causal organism of the disease Primary Amoebic Meningoencephalitis.

\section{RESULTS AND DISCUSSION}

A total of 180 mushrooms sampled over a 9 months period revealed that 176 samples $(97.77 \%)$ contained amoebae on their surfaces. The amoebae were both cyst forming as well as non cyst forming and comprised of various strains of Schizopyrenus, H artmanella, Acanthamoeba, ISSN : 0974-9411 (Print), 2231-5209 (Online) All Rights Reserved ๑ Applied and Natural Science Foundation www.ansfoundation.org 
Naegleria and Vanella sp. (Table 1, Plate1). Information about generic diversity of amoebae was obtained by direct observation of trophic and cystic stages, (Table 2) as well as by testing for the presence of amoeboflagellates by the introduction of distilled water overlaid directly into the isolation dishes. A total of 17 Naegleria strains were isolated, out of which 5 were identified as disease causing Naegleria fowleri (Table 3) and were tested for their pathogenicity as shown in Table 4. The pathogenicity test revealed that the strains 2BNf01 and 5BNf04 were mildly pathogenic while the rest three strains, $4 \mathrm{ANfO} 2_{i}$, 4ANf03 and $8 \mathrm{ANfO5}_{\mathrm{i}}$ were highly pathogenic causing cent percent mortality in experimentalalbinomice. Two strains of Naegleria fowleri, namely $4 \mathrm{ANfO} 2_{\mathrm{i}}$ and $8 \mathrm{ANf05}$, were isolated from the internal tissues of Pleurotus sajor-caju. It was also observed that the most frequently observed species of amoebae belonged to the genus Acanthamoeba and a total 103 Acanthamoeba strains recorded (Table 1). The species were identified by cyst morphology and the characteristic pseudopodial type.

Amoebae have been found associated and are isolated from a variety of edible biological products of plant origin such as Oak leaf lettuce (Lactuca sativa var. crispa) and
Boston lettuce (L. sativa var. capitata), (Napolitano and Eggolt, 2007). Recently a strain of Acanthamoeba palestenensis was also isolated from leafy vegetables (Gourabathini, 2008). Contamination by amoebae was also estimated in a two year survey of salad vegetables obtained from wholesale and retail sources. The vegetables examined were cucumbers, cabbage, lettuce, celery, carrots, radishes, tomatoes, cauliflowers and spinach. Amoebae isolated were identified as the potentially pathogenic species which included, Acanthamoeba polyphaga, A. rhysodes and A. castellanii (Rude et al.,1984). Amphizoic amoebae have been isolated from, vegetables such as turnip (Srivastava et al., 1996). Strains of Acanthamoeba culbertsoni, A. rhysodes and $\mathrm{H}$ artmanella vermiformis were isolated from carrot (Sharma et al., 2004). The discovery that amoebae may be isolated from the surface and internal tissues of the mushroom Laccaria trullisata (Napolitano and Flanagan, 1980) and from surfaces of cap and stalks of Agaricus bisporous (Napolitano, 1982) has led to related questions about the occurrence of similar relationships in other mushrooms as well. The present study is a preliminary effort to answer these questions and indicates that apart from the surface tissues of edible mushrooms,

Table 1. Showing the occurrence of FLA (free living amoebae) amoebae from P. sajor-caju (Oyster mushroom).

\begin{tabular}{|c|c|c|c|c|c|}
\hline S. No. & Batch no. & M onth & $\begin{array}{l}\text { Total number of } \\
\text { samples taken }\end{array}$ & $\begin{array}{l}\text { Total +ve samples for F LA } \\
\text { from Pleurotus sajor-caju }\end{array}$ & A moebae \\
\hline 1. & $1 \mathrm{~A}$ & Jan & 10 & 09 & Ac, $\mathrm{Hm}, \mathrm{Vn}$ \\
\hline 2. & $1 \mathrm{~B}$ & & 10 & 09 & $\mathrm{Hm}, \mathrm{Ac}$ \\
\hline 3. & $2 \mathrm{~A}$ & Feb & 10 & 10 & $\mathrm{Ng}, \mathrm{Ac}, \mathrm{Scz}$ \\
\hline 4. & $2 \mathrm{~B}$ & & 10 & 10 & $\mathrm{Scz}, \mathrm{Ng}$ \\
\hline 5. & $3 \mathrm{~A}$ & Mar & 10 & 09 & Ac, Scz \\
\hline 6. & $3 \mathrm{~B}$ & & 10 & 10 & $\mathrm{Hm}, \mathrm{Vn}, \mathrm{Ac}$ \\
\hline 7. & $4 \mathrm{~A}$ & Apr & 10 & 09 & $\mathrm{Scz}, \mathrm{Ng}$ \\
\hline 8. & $4 \mathrm{~B}$ & & 10 & 10 & Ac \\
\hline 9. & $5 \mathrm{~A}$ & May & 10 & 10 & Ac, $\mathrm{Hm}, \mathrm{Vn}$ \\
\hline 10. & $5 \mathrm{~B}$ & & 10 & 10 & Ac, $\mathrm{Ng}$ \\
\hline 11. & $6 \mathrm{~A}$ & Jun & 10 & 10 & $\mathrm{Ac}, \mathrm{Scz}, \mathrm{Ng}$ \\
\hline 12. & $6 \mathrm{~B}$ & & 10 & 10 & $\mathrm{Hm}, \mathrm{Vn}, \mathrm{Ac}, \mathrm{Scz}$ \\
\hline 13. & $7 \mathrm{~A}$ & Jul & 10 & 10 & $\mathrm{Vn}, \mathrm{Ac}, \mathrm{Scz}$ \\
\hline 14. & $7 \mathrm{~B}$ & & 10 & 10 & $\mathrm{Ac}, \mathrm{Hm}, \mathrm{Vn}$ \\
\hline 15. & $8 \mathrm{~A}$ & Aug & 10 & 10 & $\mathrm{Ac}, \mathrm{Scz}, \mathrm{Ng}$ \\
\hline 16. & $8 \mathrm{~B}$ & & 10 & 10 & $\mathrm{Hm}, \mathrm{Vn}, \mathrm{Ac}$ \\
\hline 17. & 9A & Sep & 10 & 10 & $\mathrm{Vn}, \mathrm{Ac}, \mathrm{Scz}$ \\
\hline 18. & 9B & & 10 & 10 & Ac, $\mathrm{Hm}, \mathrm{Vn}$ \\
\hline TOTA & & & 180 & 176 & $\mathrm{Ac}, \mathrm{Hm}, \mathrm{Scz}, \mathrm{Ng}$, \\
\hline
\end{tabular}

Scz- Schizopyrenus sp., Ng- Naegleria sp., Hm- Hartmannella sp., Ac- Acanthamoeba sp., Vn- Vanella sp. 

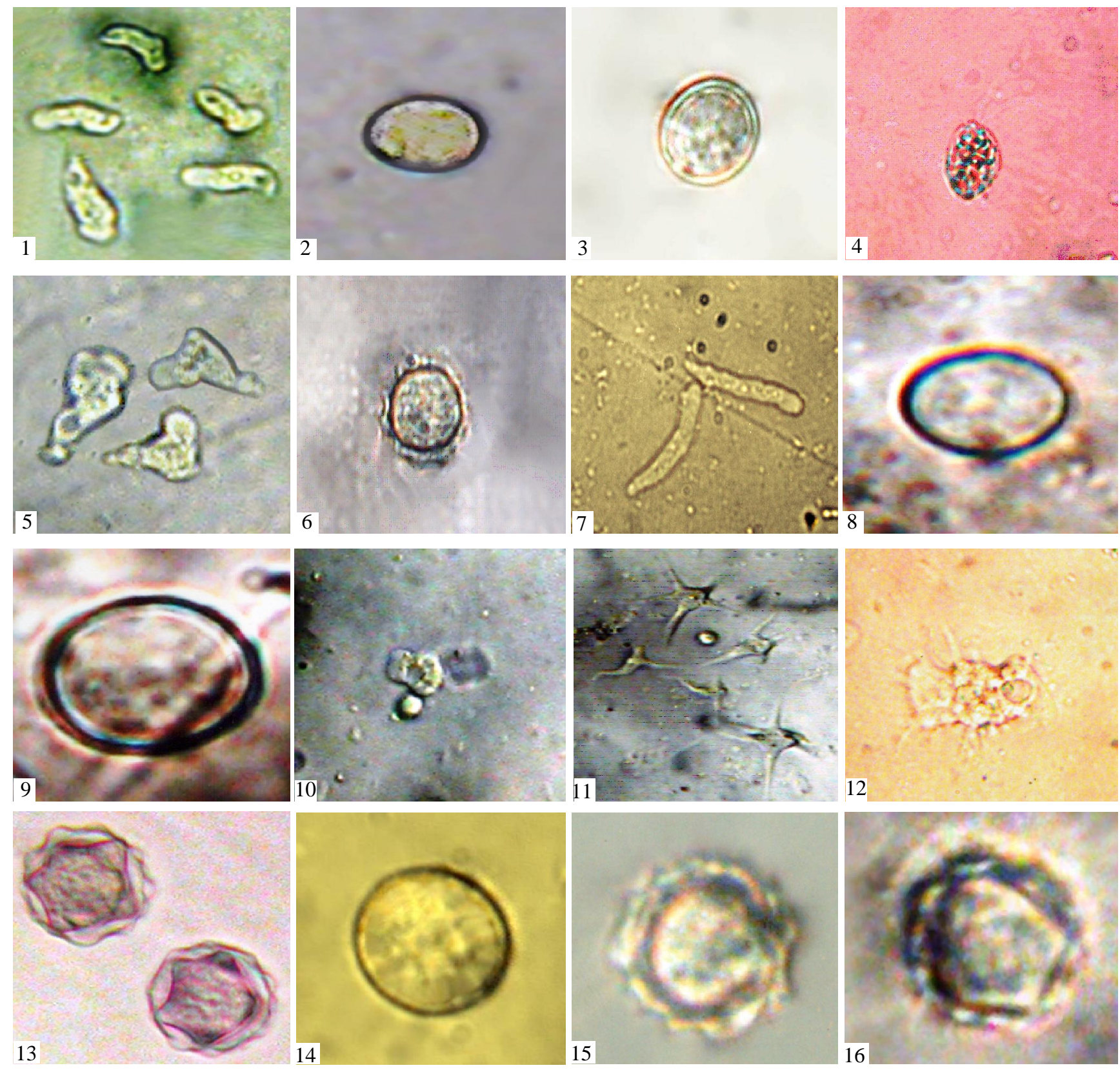

Plate 1. Fig.1-16. 1. Trophozoites of Naegleria sp.; 2. Cyst of N. fowleri; 3. Cyst of N . gruberi; 4. Amoebaoflagellate stage of Naegleria sp.; 5. Trophozoites of Schizopyrenus Sp.; 6. Cyst of Schizopyrenus Sp.; 7. Trophozoites of $\mathrm{H}$ artmanella sp.; 8. Cyst of $\mathrm{H}$ artmanella crumpae; 9. Cyst of $\mathrm{H}$ artmanella vermiformes; 10. Trophozoites of Vanella sp.; 11. Floating forms of Vanella sp; 12. Trophozoite of Acanthamoeba sp.; 13. Cyst of A. polyphaga; 14. Cyst of A.glebae; 15. Cyst of A.culbertsoni; 16. C yst of A.rhysodes. All magnifications $=10 \times 40 \mathrm{X}$.

internal tissues of mushrooms may also contain amoebae. Pleurotus sajor-caju is grown on compost made up of highly rich organic matter. As the microbial activities are mediated in the rhizosphere, it is assumed that the protozoon population would be distributed in this microhabitat as well (Rodriguez-Zaragoza, 2005) which may serve as a suitable medium for growth of aerobic amoebae as it contains various organic and inorganic compounds (Singh, 1975). Bamforth (1980) has stated the differential suitability of vegetable surfaces and root zones for the growth of soil protozoa. The temperature and $\mathrm{pH}$ of the compost in which these mushrooms grow was recorded between the range of $25-30^{\circ} \mathrm{C}$ and $4.5-5.5$ respectively. As evident by the work of previous workers, the soil amoebae tolerates wide variation of $\mathrm{pH}$ ranging from 3.9 to 9.75 (Sandon, 1927). Therefore, the temperature and $\mathrm{pH}$ of mushroom compost was found suitable for the growth and survival of amphizoic amoebae. The presence of amphizoic amoebae on compost may further increase the probability of their occurrence on the surfaces of the edible mushrooms as well (Shukla and Sharma, 2010). Napolitano (1982) has discussed about a species of 
Table 2. Showing different genera of amphizoic amoebae isolated from P. sajor-caju (Oyster mushroom).

\begin{tabular}{|c|c|c|c|c|c|c|}
\hline \multirow[b]{2}{*}{ S.No. } & \multirow[b]{2}{*}{ Batch no. } & \multicolumn{5}{|c|}{ Amphizoic amoebae } \\
\hline & & $\mathrm{Scz}$ & $\mathrm{Ng}$ & $\mathrm{Hm}$ & $\mathrm{Ac}$ & $\mathrm{Vn}$ \\
\hline 1 & $1 \mathrm{~A}$ & 0 & 0 & 1 & 6 & 2 \\
\hline 2 & $1 \mathrm{~B}$ & 0 & 0 & 2 & 7 & 0 \\
\hline 3 & $2 \mathrm{~A}$ & 1 & 2 & 0 & 7 & 0 \\
\hline 4 & $2 \mathrm{~B}$ & 6 & 4 & 0 & 0 & 0 \\
\hline 5 & $3 \mathrm{~A}$ & 5 & 0 & 0 & 4 & 0 \\
\hline 6 & $3 B$ & 0 & 0 & 1 & 8 & 1 \\
\hline 7 & $4 \mathrm{~A}$ & 5 & 4 & 0 & 0 & 0 \\
\hline 8 & 4B & 0 & 0 & 0 & 10 & 0 \\
\hline 9 & $5 \mathrm{~A}$ & 0 & 0 & 2 & 4 & 4 \\
\hline 10 & $5 \mathrm{~B}$ & 0 & 4 & 0 & 6 & 0 \\
\hline 11 & $6 \mathrm{~A}$ & 3 & 1 & 0 & 6 & 0 \\
\hline 12 & $6 \mathrm{~B}$ & 1 & 0 & 1 & 7 & 1 \\
\hline 13 & $7 \mathrm{~A}$ & 1 & 0 & 0 & 8 & 1 \\
\hline 14 & $7 \mathrm{~B}$ & 0 & 0 & 3 & 4 & 3 \\
\hline 15 & $8 \mathrm{~A}$ & 1 & 2 & 0 & 7 & 0 \\
\hline 16 & $8 \mathrm{~B}$ & 0 & 0 & 1 & 6 & 3 \\
\hline 17 & $9 \mathrm{~A}$ & 2 & 0 & 0 & 5 & 3 \\
\hline 18 & $9 \mathrm{~B}$ & 0 & 0 & 1 & 8 & 1 \\
\hline TOTAL & & 25 & 17 & 12 & 103 & 19 \\
\hline PERCENTAGE & & $14 \%$ & $10 \%$ & $7 \%$ & $58 \%$ & $11 \%$ \\
\hline TOTAL FLA & & & & 176 & & \\
\hline
\end{tabular}

Table 3. Showing different species of Naegleria isolated from P. sajor-caju (Oyster mushroom).

\begin{tabular}{lcccc}
\hline \multirow{2}{*}{ S.No. } & \multirow{2}{*}{ Batch No. } & \multicolumn{2}{c}{ Naegleria sp. isolated } & \multirow{2}{*}{ Total Naegleria Strains } \\
\cline { 3 - 4 } & & N. gruberi & N. fowleri & \\
\hline 1 & $2 \mathrm{~A}$ & 3 & 0 & 4 \\
2 & $2 \mathrm{~B}$ & 2 & 1 & 4 \\
3 & $4 \mathrm{~A}$ & 3 & 2 & 4 \\
4 & $5 \mathrm{~B}$ & 1 & 1 & 1 \\
5 & $6 \mathrm{~A}$ & 2 & 0 & 2 \\
\hline 6 & 8A & 12 & 1 & 17 \\
\hline TOTAL & $71 \%$ & $29 \%$ & - \\
\hline PERCENTAGE & & & 5 \\
\hline
\end{tabular}

Table 4. Showing pathogenicity of amoebic isolates in albino mice.

\begin{tabular}{ccccc}
\hline S. No. & B atch No. & Strains & No. of mice & Death time of mice in days \\
\hline 1 & 2B & 2BNf01 & 6 & $6,12,16,18, \mathrm{~S}+, \mathrm{S}+$ \\
2 & 4A & 4ANf02 ${ }_{\mathrm{i}}{ }^{*}$ & 6 & $5,5,7,8,9,10$ \\
3 & 4A & 4ANf03* & 6 & $3,5,6,7,8,11$ \\
4 & $5 \mathrm{~B}$ & $5 \mathrm{BNf04}$ & 6 & $7,12,16,20, \mathrm{~S}+, \mathrm{S}+$ \\
5 & $8 \mathrm{~A}$ & $8 \mathrm{ANf05}{ }_{\mathrm{i}}{ }^{*}$ & 6 & $5,5,6,7,8,11$ \\
6 & - & Control (Eschrerichia coli) & 6 & $\mathrm{~S}, \mathrm{~S}, \mathrm{~S}, \mathrm{~S}, \mathrm{~S}, \mathrm{~S}$ \\
\hline
\end{tabular}

$\mathrm{S}=$ mice surviving upto 21 days, $\mathrm{S}+=$ mice surviving upto 21 days and with positive amoebic culture from brain cultured on $22^{\text {nd }}$ day, ${ }^{*}$ - Pathogenic strains causing mortalities in laboratory albino mice, $4 \mathrm{ANf0} 2_{i}^{*}$ and $8 \mathrm{ANf05}_{i}^{*}$ isolated from internal tissues of P. sajor-caju 
mushroom, L. trullisata yielding amoebae from internal tissues. It is suggested that the associations between amoebae and mushrooms may be widespread and the ways in which amoebae and mushrooms associate in nature need further attention. For example, if the association is initially at the mycelial stage, as has been postulated in the case of $L$. trullisata. It might also be asked whether the mycelial stage of edible mushrooms produces factors or creates conditions for such an association in their environment. The answers to these and other questions posed by this new information about amoebae-mushroom relationships are of great interest to biologists and mushroom growers. Because soil amoebae are recognized as pathogens (Duma, 1972.) and because virulent and nonvirulent amoebae have been obtained from lettuce, radishes, cucumbers, cabbage, celery, carrots, tomatoes, cauliflowers, spinach and onions (Rude et al., 1984; Clurea-Varl Saanen, 1981) the role of vegetables in transmitting amoebae to humans must be evaluated.

\section{ACK NOWLEDGEMENTS}

We are thankful to Head of the Department, Zoology, University of Lucknow, for providing necessary laboratory facilities to carry out this work. Thanks are also due to my loving husband, Mr. Anand Dwivedi who not only helped me during the finalization of this paper but also for inspiring and refreshing me with all his affection, time to time, while I was composing this paper.

\section{REFERENCES}

Bamforth, S. S. (1980). Terrestrial Protozoa. J ournal of Protozoology, 27 (1) : 33-36.

Clurea-Varl Saanen, M. (1981). L'isolement d'amibes libres dans le sol et les legumes; etude morphologique et pathogenique des souches isolees. Rev. Med. Suisse Romande, 101:229-238.

Duma, R. J. (1972). Primary amoebic meningoencephalitis. Crit. Rev. Clin. Lab. Sci., 3:163-192.

Gourabathini, P., Brandl M. T., Redding K. S., Gunderson J. H. and Berk, S.G. (2008). Interactions Between Foodborne Pathogens and Protozoa Isolated from Lettuce and Spinach. Appl. Environ. Microbiol., 74 : 2518-2525.

Levine, N. D., Corliss, J. O., Cox. F. E. G., Deroux, G., Grain,
J., Honigberg, B. M., Leedale, G. F., Loeblick, A. R., Lom, J., Lynn, D., Merinfeld, E. G., Page, F. C., Polijansky, G.,ra Sprague, V., Vavra, J. and Wallance, F. C. (1980). The newly revised classification of Protozoa. J . Protozool., 27: 37-58.

Napolitano, J. J. (1982). Isolation of amoebae from edible mushrooms. Applied and Environmental Microbiology, 44 (1): 255-257.

Napolitano, J. J. and Flanagan, V. D. (1980). Occurrence of amoebae in and around the mushroom Laccaria trullisata. J. Protozool., $28: 494-497$.

Napolitano, J. J. and Colletti-Eggolt C. (2007). Occurrence of Amoebae on Oak Leaf Lettuce (Lactuca sativa var.crispa) and Boston Lettuce (L. sativa var. capitata). J ournal of Eukaryotic Microbiology, 31 (3): 454 - 455.

Rodriguez-Zaragoza, S., Mayzlish, E. and Steinberger, Y. (2005). Vertical distribution of the free-living amoeba population in soil under desert shrubs in the Negev desert, Israel. Appl. Environ. M icrobiol., 71 (4): 2053-2060.

Rude, R. A., Jackson, G. J., Bier, J. W., Sawyer, T. K., Risty, N. G. (1984). Survey of fresh vegetables for nematodes, amoebae, and Salmonella. J ournal Association of Official Analytical Chemists, $67: 613-615$.

Sandon, H. (1927). The composition and distribution of the protozoan fauna of the soil. Oliver and Boyd, Edinburgh.

Sharma, A. K., Pandey, R. and Pandey, K. (2004). A report on the occurrence of amphizoic amoebae from carrot. Flora and F auna, 10 (2): 141-143.

Shukla, K. and Sharma, A. K. (2010). Studies on protozoans with special reference to amphizoic amoebae being isolated from edible biological products. Ph.D. Thesis. Department of Zoology, University of Lucknow, Lucknow. India

Singer, R. (1949). The Agaricales in modern taxonomy. Lilloa, 22: 387

Singh, B. N. (1981). Nuclear division as the basis for possible phylogenic classification of the order Amoebida Kent, 1880, Ind. . . Parasitol., 5: 133-153.

Singh, B. N. and Hanumaiah, V. (1979). Studies on pathogenic and non-pathogenic amoebae and the bearing of nuclear division and locomotion form and behavior on the classification of the order amoebida. Monograph no. 1 of the Association of Microbiologists of India. Indian J . Microbiol., 1-80.

Singh. B. N. (1975). Pathogenic and non-pathogenic amoebae. Wiley \& Sons, New York.

Srivastava, A., Sharma, A. K., and Jaiswal, K. (1996). Isolation of pathogenic Acanthamoeba rhysodes from Turnip. Biol. Memoirs, 22 (2): 87-89. 